
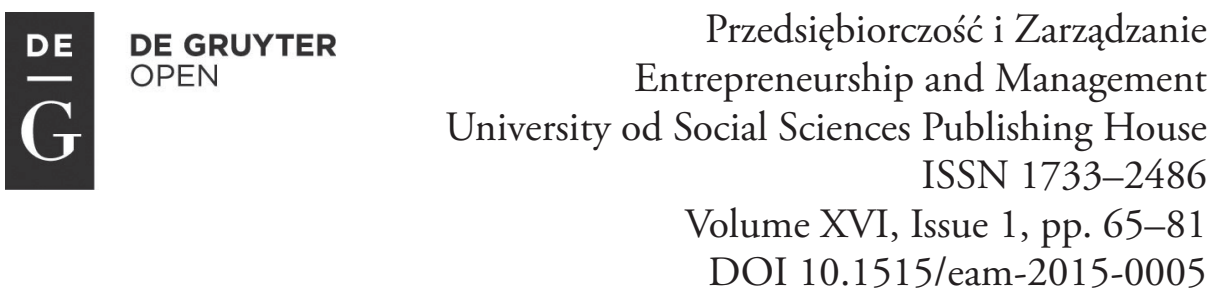

Agnieszka Kłysik-Uryszek

University of Lodz

\title{
Equity Investments vs. Debt Investments - What Drives OFDI in Polish Industry
}

\begin{abstract}
:
Polish economy witnessed enormous changes over the past 25 years. Systematic economic growth, increasing market openness, legal stabilization and integration with EU have substantially improved Poland's global competitive position. That is reflected, among others, in intensified flows of long-term capital in the form of foreign direct investment (FDI). What is worth stressing, the last decade (regardless the economic crisis) brought a significant rise of investments made by Polish companies abroad (Outward FDI). It should be mentioned however, that the FDI flows are usually analyzed (in both theoretical and empirical literature) as if they consist only of equity investments, when in fact they consist also of intracompany loans. As the latter may not be driven by the same factors as equity flows, the real structure of FDI flows should be taken into consideration while evaluating the investment potential of companies. The paper examines selected issues concerning international expansion of Polish companies in the form of foreign direct investment. It provides theoretical background of the problem, explores the reasons for expansion and presents the structure of foreign direct investment by Polish industrial companies in the period 2003-2012 with regard to the equity and debt components of the flows. The study is based on the data provided by the National Bank of Poland (NBP).
\end{abstract}

Key words: OFDI, internationalization, international equity and debt investments, Polish enterprises.

JEL Classifications: F21, F23 


\section{Introduction}

Intense globalisation, regionalisation and liberalisation that took place in recent years in the global economy have created new conditions for business operations. Classical national markets have lost importance in favour of more and more accessible international markets. Besides, continued disproportions in relative availability (and costs) of production factors between countries and differences in the cost of manufacturing encourage companies to seek the most convenient locations for their businesses outside of their home countries. So far Poland has been internationally perceived as an attractive investment location.

Although inflows of capital into the Polish economy still exceed the outflows (i.e. Poland remains net importer of foreign capital), the last decade witnessed also increasing expansion of Polish companies through outward foreign direct investment (OFDI). This relatively fresh tendency confirms the growth of Polish economy and the change of its international competitive and investment position. However, one should remember, that the FDI statistics based on balance of payment distinguish two main types of flows: equity investments and intracompany short-term and long-term loans. Usually, the equity investments are perceived as primary ones, while debt seems to be subsequent. As the latter may by driven by different factors than the equity flows, the aggregated value of OFDI provided by official statistics may not reflect the real potential of home companies.

The paper aims at explaining the sources of competitive advantages of Polish entities that enabled them to engage successfully in OFDI, as well as at providing some verification of scale and the structure of foreign direct investment of Polish companies, in particular in the industrial sector. The main stress is put on the distinction between equity and debt investments in order to asses the real expansion potential of the companies.

The article is structured as follows. The first part highlights the research problems against existing literature and available data. The main research questions have been formulated as well. Second one explains the sources of international competitiveness and strength to expand achieved by companies covered by the study against selected theoretical concepts, which explain the FDI. The third part discusses the scale as well as sectoral structure of the FDI of Polish manufacturing companies with regard to their equity and debt components. Main findings are presented in conclusions. The analysis covers the period of 2004-2012. 


\section{Research questions and data}

In the theoretical models, especially those based on industrial organization economies, FDI are understood mostly as equity flows which result from national factors and existing market imperfections [Caves 1971, Hymer 1976, Rugman 1981]. International expansion (i.e. FDI) of a company is effective only when several conditions appear, among which the initial strong competitive advantages of the investor is crucial. Having examined those theories one can think, that FDI flow consist only of equity flows generated by the strongest companies in the internationally competitive branches. "FDI data are often apprised as if they consist exclusively of new equity flows, when in fact they also include reinvested earnings as well as short-term and longtern intra-company debt flows" [Salorio, Brewer 2000]. But most of existing literature fail to distinguish between two types of investments.

In the first stage of active internationalisation of the economy one should expect the first type of flow (new direct equity investment) to increase and, consistently, to expand the ownership of foreign assets. If mentioned in theoretical analysis, intracompany loans are perceived as subsequent flows to the equity ones - the company must set up a foreign subsidiary (which is an initial equity investment) in order to be able to generate internal debt flows afterwards. But yet, if the multinational (MNE) sets up an entity in a host country, the latter may occur also between this foreign affiliate and its parent-company (if so, debt flows will be subsequent to the IFDI equity flows not OFDI equity flows). Therefore, important and increasing share of intracompany loans, especially when not preceded by OFDI equity flows, may confirm the domination of multinational corporations over domestic novice investors. Taking into consideration the amount of foreign subsidiaries located in Poland, we may expect that a significant part of outward debt investments made by Polish entities are just a part of international capital flows within a MNE.

While examining OFDI issues, one should remember that equity flows and debt flows may be driven by different factors. Equity flows usually reflect international competitive potential of the home company, while the latter take advantage of flexibility of multinational system [Kogut 1983]. Debt linkages may arise from the strategic decision of mother-company, i.e. when some of the foreign entities are in need or, when favorable conditions on the financial market of host country appear ${ }^{1}$.

1 Some researches try to explain intracompany debt flows on the background of financial economics emphasizing the role of interest rates, exchange rates and inflation [Aliber 1970] or even tax rates [Hartmann 1984, 1985] in creating FDI. 
All in all, the cumulated values of OFDI presented in official statistics may not entirely reflect real international competitiveness of Polish enterprises, as debt components other than equity made the scale of FDI (and OFDI) bigger than it really is. Therefore two main research questions were formulated for the paper:

1. To what extent the total value of OFDI reflect competitive potential of Polish industrial companies?

2. Are there any sectoral differences in OFDI flow composition, and if so, what can be the explanation?

In order to asses the scale of Polish OFDI with regard to the above mentioned problems, the data provided by the National Bank of Poland (NBP) have been used. NBP divides the total FDI flow into two main streams. The first one, which can be considered as "primary investment" consist of initial equity investments and reinvested profits/earnings (retained dividends). They rise value of assets owned by foreign investors abroad. The second type of flows includes all loans granted by Polish entity to related affiliates within a capital group (intracompany loans). This breakdown allows to measure to what extent Polish entities are strong enough to start their own investments abroad and in what part they are just a source of capital for parent-multinational in need.

\section{Theoretical background of the expansion of Polish companies in the form of FDI}

During the last 25 years Polish economy experienced exceptional economic and systemic transformation. Gradual and uninterrupted (even during the financial crisis) economic growth and development, accumulation of capital linked with structural changes in the economy ${ }^{2}$ and integration with the EU market have considerably altered the competitiveness and comparative advantages of the Polish economy. From being an economy in transition Poland has evolved to an industrialised developed country. Although dominant advantages are still found in traditional industries, manufacturing in modern, technically advanced industries and services develops quickly, in particular in recent years.

The above has also largely influenced the scale of international capital links and the change of international investment position of Poland, especially in the area of FDI. Despite remaining the net importer of capital, Polish econ-

2 Dominant labour and resource-intensive industries have been partly replaced by technologically advanced manufacturing. 
omy get more and more exporter of capital in the form of FDI. Some macroeconomic concepts of FDI, in particular the idea of an Investment Development Path (IDP) by J.H. Dunning [1981; 1986] and dynamic theory of economic development and competitive advantage of T. Ozawa [Ozawa 1992; Kłysik-Uryszek 2012] draw attention to the impact of economic development on the scale, structure and directions of FDI capital flows. They highlight the relationship between the stage of economic development of a country and its investment position. Empirical verification of these models [Gorynia, Nowak, Wolniak 2007, Gorynia, Nowak, Wolniak 2009, Wysokińska 2008] confirm that Polish economy is currently in the stage characteristic for gradual capital expansion. Increasing international involvement of domestic companies seems thus a natural outcome of the changing structure of economic assets and comparative advantages. Saturation of the domestic market and increasing cost of manufacturing make domestic businesses seek other location advantages on foreign markets. It becomes easier and easier due to largely improved competitiveness of Polish enterprises, which reflects the balance of competitive forces in the economy, and increasing liberalization and openness of world economy.

If a business wishes to effectively grow through OFDI, according to the idea of OLI by J.H. Dunning [1988], three groups of requirements must be fulfilled concurrently. Firstly, the company must have some strong ownership advantages ${ }^{3}$. They will help it remain profitable and competitive on international market despite significant costs and difficulties involved in internationalisation. Ownership advantages may take different forms: financial, technological, organisational, marketing, etc. Their exploitation on international market leaves the company flexible and competitive even when it must manage geographically dispersed units operating in different economic systems and circumstances.

For over twenty years Polish companies have been exposed to the competition of multinational corporations on the domestic market. It seems that the winners have already managed to work out competitive advantages, which let them operate effectively also in the international environment. Not only do they have material, marketing and organisation skills but, in some cases, also technological skills. It is worth highlighting that technological advantages do not have to be equivalent of absolute domination over all other market operators. Strong position in the industry suffices. Few Polish businesses get involved in international competitive struggle in modern high-tech sectors but

3 The paper uses the term „ownership advantages" in the meaning of the idea of OLI by J.H. Dunning and the theory of ownership advantage by S. Hymer. 
companies representing traditional industries, in which Poland enjoys well established comparative advantages, perform very well on foreign markets.

The second type of advantages necessary for foreign expansion includes internalization advantages. They arise when it is more profitable for a company to have its own unit abroad rather than trade or license a process (or all production) to an independent cooperator (outsourcing). That seems particularly difficult in recent years because of increased international specialisation leading to intense proliferation of outsourcing not only in the service sector but also in manufacturing. However, the advantage of foreign direct investment consists in the reduction of the costs of transaction and the protection of existing ownership advantages (e.g., technology, know-kow). Even though subcontracting agreements precisely specify the rules of collaboration between the parties, there is always a threat of uncontrolled dissemination of technological solutions $s^{4}$. It is also worth stressing that some attention on this aspect of FDI is drawn in the appropriability theory [Magee 1977].

Polish companies, which enter foreign markets mostly to win new customers and increase sales [Karaszewski 2012, Umiński 2009, ss. 103-104], consider retaining their ownership advantages vital. Nevertheless, the reduction of transaction costs seems the most important. The cost of seeking new partners and double-checking their reliability on unstable Eastern markets (Ukraine, Russia), costs of negotiations and the risk involved represent a serious burden. To minimise them, companies often decide to open their own manufacturing or trade branches abroad 5 .

Location advantages, the third element compulsory for successful FDI, concern the attractiveness of selected foreign markets and describe the characteristics of international environment. Such advantages may be linked to the size of the market, its growth dynamics but also to the attractiveness of resources (e.g. raw materials), production factors (e.g. cheap labour), and favourable legal and administrative arrangements (low taxes, financial incentives, administrative support).

Liberalisation and globalisation of the world economy encourage companies to look for new, better locations that can offer more suitable conditions for manufacturing and sales. The advantages consist not only in the access to new markets but also in global differences in prices of factors of production

4 It is well reflected in recently renowned case of Apple against Samsung, which was accused of using the design and solutions developed by Apple. That was enabled by the fact that Apple outsourced the manufacturing of its flagship products to Samsung.

5 In that case OFDI support export of a company which is very desired from the GDP growth perspective. 
(mainly labour). By reducing costs, companies may maintain or even improve their profitability and productivity, despite increasing competition, not only on the host markets but also globally [Stempkowicz 2007, ss. 3-4]. Moreover, the establishment of Special Economic Zones, that favour foreign investors, becomes an important incentive for FDI.

The OLI paradigm is the best known and universally accepted idea, which describes the conditions necessary to start FDI. We must bear in mind, however, that FDI is the most advanced form of internationalisation of companies. Businesses usually start expansion from exports and then, having got better acquainted with the global market, they decide (as a result of various factors) on a more advanced forms of their presence on international markets. The processes are widely described in literature as stage models or behavioural models of internationalization [Johanson, Vahlne 1977; Kłysik-Uryszek, KunaMarszałek 2014].

When it comes to the sources of international expansion of Polish companies, network models should be mentioned. They highlight the role of being a part of international network of economic relations and should be analysed taking account of the experiences of Polish companies. The latter relatively often stress the importance of cooperation for the decision on FDI - most often they follow their key collaborator [Umiński 2009] - active involvement into the network of his international links but also the imitation of the market leader.

When analysing outward foreign direct investment originating from Poland, attention should be drawn to the fact that the population of residents of the Polish economy includes not only businesses with Polish capital but also companies with foreign capital, including those owned by international capital groups. A substantial portion of Polish OFDI includes the investment made by foreign-owned companies located in Poland. As suggested by the statistics of the Central Statistical Office (GUS), they account for ca. 60\% investment projects classified as Polish FDI [Kłysik-Uryszek 2012]. Polish units owned by multinational corporations embark on further foreign expansion following strategic decisions of the parent company, not based on their own ownership or internalisation advantages. Thus we can hardly assess their expansion based on the criteria applied to businesses with domestic capital, much less experienced in internationalisation, which must seek information about foreign markets, identify their attractiveness and estimate risk on their own. The challenge for them is much bigger than for global firms. Hence their successes may become a better measure of development and international competitiveness. 


\section{Structure of Polish foreign investment in manufacturing}

OFDI is a relatively new phenomenon in the Polish economy. Intensified capital exports in the form of foreign direct investment started after Poland's EU accession. Economic downturn has not weakened the tendency, on the contrary, since 2010 a significant increase in the value of Polish OFDI has been observed. Data by the NBP (from the statistics of balance of payments) indicate that at the end of 2012 cumulated value of Polish investment was almost PLN 180 bn and represented less than 12\% of GDP - see diagrams 1 and 2.

\section{Diagram 1. OFDI to GDP ratio in Poland for the years 1995-2012}

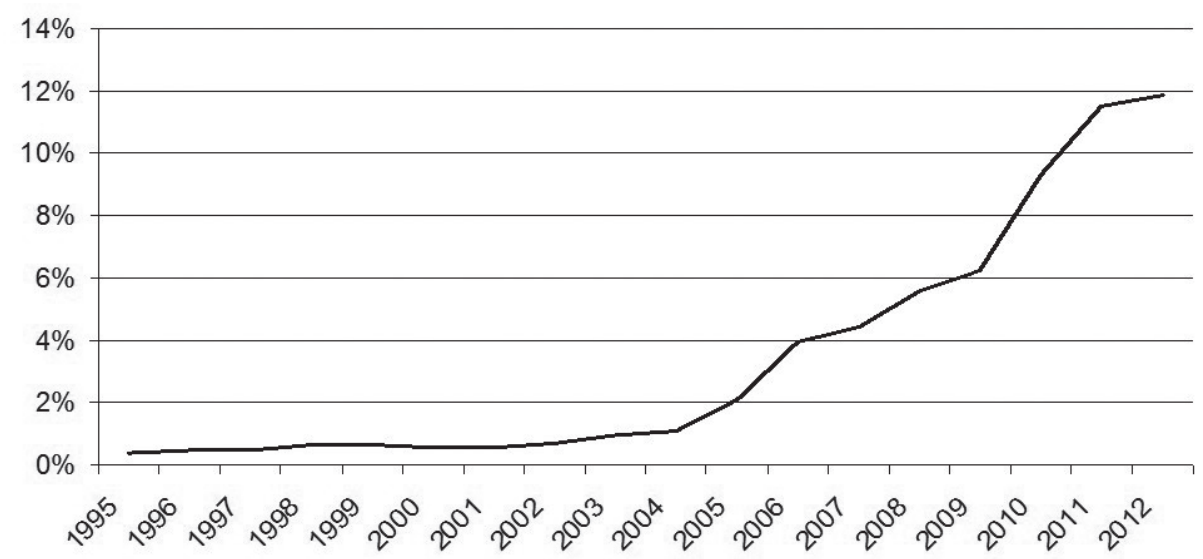

Source: own calculations on the basis of NBP data (balance of payments)

As for the analysis of the structure of outward FDI of Polish companies we may notice the increasing share of the second type of investment flows - see diagrams 2 and 3. Both of the components rose for the whole period of the study. Equity investments showed relative stable growing tendency (with the exception of 2010, when the increase was quite small), while intracompany loans surged drastically in 2010. It should be stressed however, that it was not only due the real debt flows growth, but to the change in methodology of collecting data. Up to 2009, only the flows between parent company and its direct subsidiary was considered FDI. Since 2010 all loans granted among related companies within a capital group have been considered FDI. The values shown on diagram 2 and 3 show the extent to which Polish entities served as international lenders. 


\section{Diagram 2. OFDI stock of Polish companies}

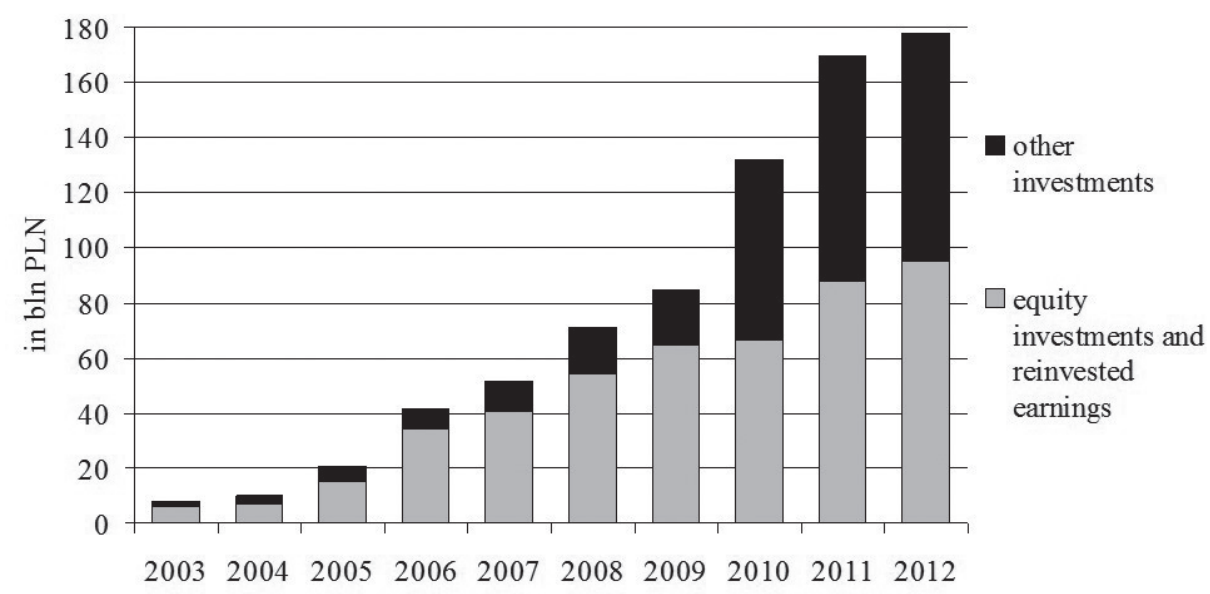

Source: own calculations based on the NBP data, http://www.nbp.pl/home.aspx?f=/publikacje/pib/pib.html, access on 15.12.2013.

Between the years 2003-2005 investment of industrial companies accounted for ca. $18 \%$ of the total Polish OFDI. In the following 4 years, the share dropped to $10 \%-15 \%$ to increase substantially, even up to $38 \%$ in 2010. In 2012, industry generated about 35\% of total OFDI stock of Polish companies. However, it is worth stressing that throughout the entire period the share of industrial companies in total primary investments of Polish entities did not exceed $10 \%$ until 2009 , then it skyrocketed to $32 \%$ in 2010 to drop again in the following years down to $17 \%$ in 2012 . On the contrary, the share in intracompany loans was much above the average. That might mean, that the industrial companies were more often the source of loan capital for other overseas members of a capital group than in the service businesses.

In the period 2003-2011 annual foreign direct investment flows of Polish industrial companies were very much volatile - see diagram 3 . The lowest values were recorded for 2003, 2004, and 2008 while the highest for 2006. Remarkably, after the drop in investment in the crisis year 2008, already in 2009 the expansion of Polish companies reached almost PLN 8 bn. This confirms relatively strong position of Polish companies and not severe course of the crisis. Also in the following years, 2010 and 2011, high investment values were retained accompanied by significantly higher share of other investment in the flows of industrial OFDI. It proves again that, paradoxically, in the times of economic crisis Polish economy became the source of loan capital for related 
foreign entities. Already in 2012 the capital returned to Poland, which may provide evidence of improved financial standing of the borrowers and the end of crisis.

\section{Diagram 3. OFDI (flows) of Polish industrial companies}

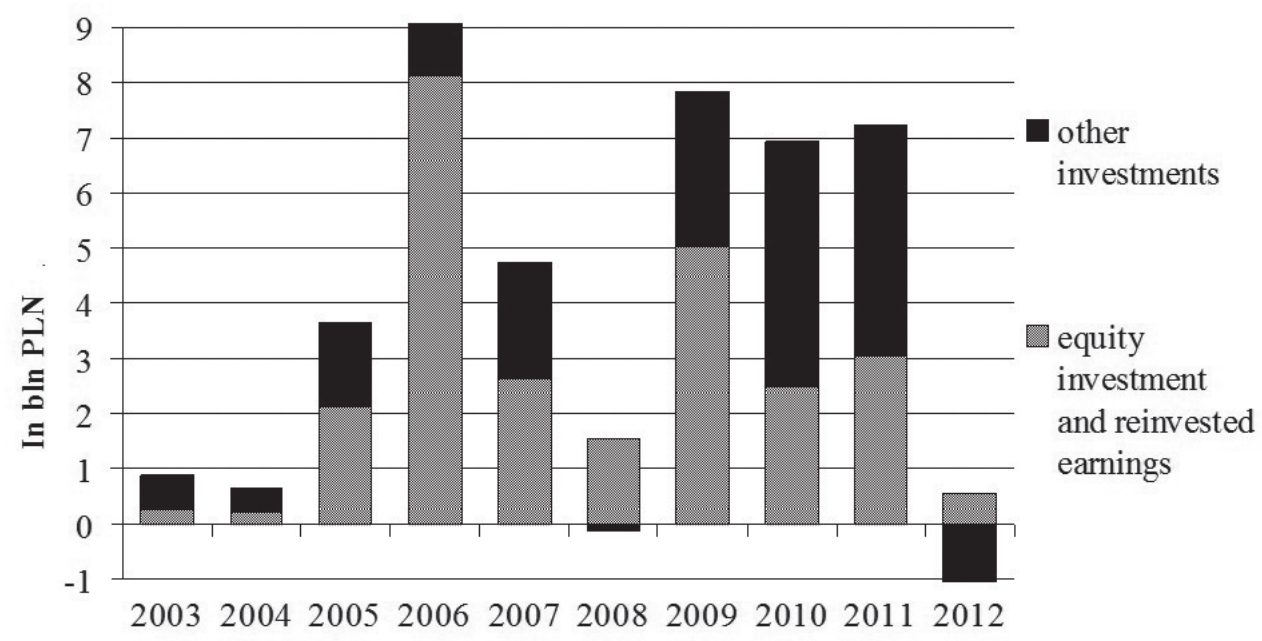

Source: own calculations based on the NBP data, http://www.nbp.pl/home.aspx?f=/publikacje/pib/pib.html, access on 15.12.2013.

Throughout the whole period covered by the study, investments of manufacturing companies represented the major part of investment of the industrial sector. Mining played a minor role, similarly to construction (with the only exception of 2011 when construction companies invested in total more than PLN 2.7 bn). Operators dealing with electricity and natural gas generation and distribution were a bit more active. Since 2007 they invested respectively ca. PLN 1 bn, PLN 300 mio, PLN 900 mio, PLN 1.2 bn, and PLN 500 mio.

In most of the years subject to the analysis, foreign equity investment were the main constituent of FDI flows in industrial companies. Gradually, also intracompany loans were increasing. Their share in the last two years of the period significantly exceeded $50 \%$ and it was higher than the FDI of service operators in the entire period. Not only manufacturing companies were involved in such loans (as presented in detail in Table 1) but also other industrial companies operating in the field of mining, distribution of energy or construction. 


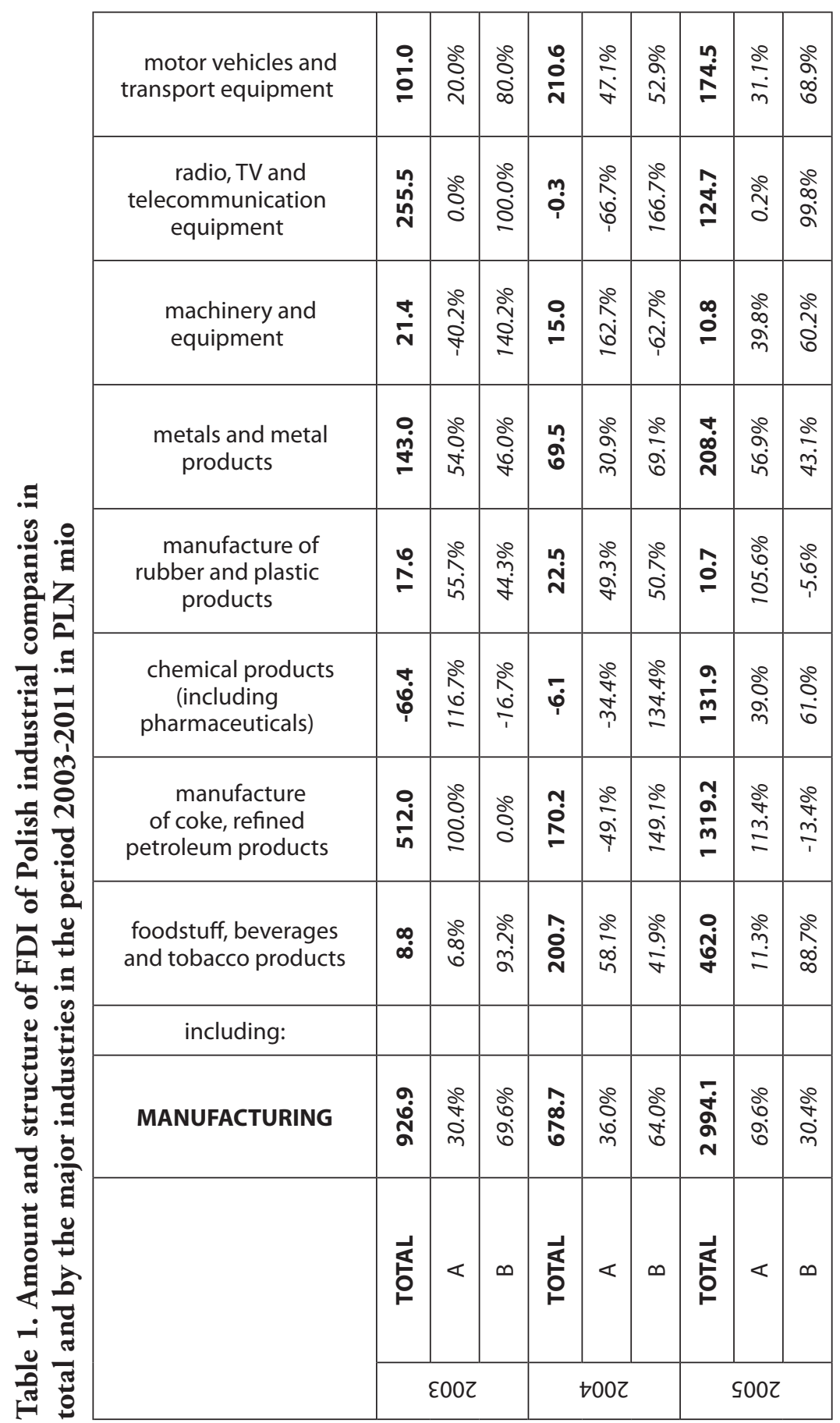




\begin{tabular}{|c|c|c|c|c|c|c|c|c|c|c|c|c|c|c|c|c|c|}
\hline$\stackrel{+}{\check{E}}$ & $\begin{array}{l}\stackrel{0}{0} \\
\stackrel{2}{人}\end{array}$ & $\begin{array}{l}\infty_{0}^{0} \\
\text { ஸे }\end{array}$ & $\stackrel{n}{\wedge}$ & $\begin{array}{l}\stackrel{\circ}{~} \\
\text { จे }\end{array}$ & $\begin{array}{l}\text { ঠे } \\
\stackrel{0}{0}\end{array}$ & 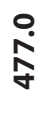 & 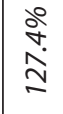 & 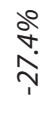 & $\begin{array}{l}\text { Na } \\
\text { ׁo } \\
\dot{\sigma}\end{array}$ & $\frac{\grave{\delta}}{\frac{\delta}{m}}$ & $\begin{array}{l}\text { ठे } \\
\text { बें }\end{array}$ & $\begin{array}{l}\text { ָ } \\
\text { J }\end{array}$ & $\begin{array}{l}\text { dे } \\
\text { ஸे }\end{array}$ & 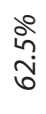 & $\begin{array}{l}\infty \\
\infty \\
\stackrel{0}{0} \\
\stackrel{n}{n} \\
m\end{array}$ & $\begin{array}{l}\text { ठ̊ } \\
\stackrel{0}{0}\end{array}$ & $\begin{array}{l}\text { ஓे } \\
\text { จे }\end{array}$ \\
\hline$\frac{\sigma}{\mathscr{0}}$ & $\begin{array}{l}\stackrel{d}{\dagger} \\
\text { ণ }\end{array}$ & $\begin{array}{l}\text { ठீ } \\
\text { ळे }\end{array}$ & $\stackrel{0}{N}$ & $\begin{array}{l}\text { ঠ̊ } \\
\text { ஸे }\end{array}$ & $\begin{array}{l}\stackrel{+}{+} \\
\text { ๙̆ }\end{array}$ & ஸे & $\begin{array}{l}\text { ১े } \\
\infty \\
\text { p. }\end{array}$ & $\begin{array}{l}\text { ○े } \\
\text { ○ं } \\
0\end{array}$ & $\begin{array}{l}\text { பீ } \\
\infty \\
\infty\end{array}$ & $\frac{\stackrel{2}{\circ}}{\frac{1}{1}}$ & $\begin{array}{l}\stackrel{\circ}{\circ} \\
\stackrel{0}{ }\end{array}$ & $\begin{array}{l}\infty \\
\frac{\infty}{\infty} \\
\sigma\end{array}$ & ஃ̊ & $\frac{2}{\text { वे }}$ & ণ্ণু & $\begin{array}{l}\text { ठ̊ } \\
\text { ه̊ }\end{array}$ & 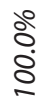 \\
\hline ร் & $\begin{array}{l}\text { ठे } \\
\text { ঋे }\end{array}$ & $\begin{array}{l}\text { ठे } \\
\text { जी } \\
\text { जी }\end{array}$ & $\begin{array}{l}n \\
\infty \\
\infty\end{array}$ & $\begin{array}{l}\text { ळे } \\
\dot{m}\end{array}$ & $\frac{20}{60}$ & مٌ & $\frac{\delta^{\circ}}{\text { in }}$ & $\frac{\stackrel{d}{\infty}}{\stackrel{\infty}{+}}$ & กุ & ه̊ & $\begin{array}{l}\text { ठे } \\
\text { बे }\end{array}$ & $\begin{array}{l}\stackrel{\leftrightarrow}{\sim} \\
\stackrel{\sim}{N}\end{array}$ & $\begin{array}{l}\stackrel{\circ}{ } \\
\stackrel{+}{ \pm}\end{array}$ & $\begin{array}{l}\text { ১o } \\
\text { ஸे } \\
\infty\end{array}$ & స્ & $\frac{d 0}{\grave{d}}$ & $\begin{array}{l}\stackrel{0}{~} \\
\stackrel{0}{~}\end{array}$ \\
\hline $\begin{array}{l}\infty \\
\stackrel{\sim}{N} \\
\text { N }\end{array}$ & $\begin{array}{l}\text { ळे } \\
\infty \\
\infty \\
\omega^{\circ}\end{array}$ & $\frac{\stackrel{d}{\sigma}}{\sigma}$ & ז் & $\begin{array}{l}\stackrel{0}{ } \\
\stackrel{\text { }}{N}\end{array}$ & $\begin{array}{l}\stackrel{0}{\tilde{m}} \\
\stackrel{1}{N}\end{array}$ & $\begin{array}{l}\dot{J} \\
\dot{J}\end{array}$ & $\frac{\text { oे }}{\infty}$ & $\frac{d^{\circ}}{\infty}$ & $\begin{array}{l}\text { m̊. } \\
\text { N } \\
\text {. }\end{array}$ & $\begin{array}{l}\stackrel{2}{\aleph} \\
\stackrel{N}{N}\end{array}$ & 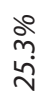 & กิ & 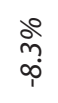 & $\begin{array}{l}\stackrel{0}{ } \\
0 \\
\infty \\
0\end{array}$ & $\begin{array}{l}\text { षें } \\
\text { ஸे } \\
\infty\end{array}$ & $\begin{array}{l}\stackrel{0}{~} \\
\text { oे } \\
\sigma\end{array}$ & 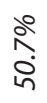 \\
\hline$\stackrel{n}{m}$ & 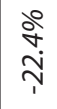 & $\begin{array}{l}\stackrel{0}{\forall} \\
\underset{N}{ }\end{array}$ & $\begin{array}{l}m \\
\infty \\
\infty \\
0\end{array}$ & $\begin{array}{l}\text { ठ̊ } \\
\stackrel{0}{0}\end{array}$ & $\begin{array}{l}\stackrel{+}{+} \\
\text { iे } \\
\text { r. }\end{array}$ & $\begin{array}{l}m \\
\text { ò } \\
\text { m}\end{array}$ & 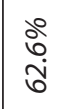 & 犬̊ & 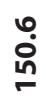 & $\begin{array}{l}\text { ১o } \\
\text { जे }\end{array}$ & $\begin{array}{l}\text { ठొ } \\
\stackrel{+}{ }\end{array}$ & $\frac{0}{0}$ & $\begin{array}{l}\text { ठे } \\
\text { }\end{array}$ & $\frac{20}{6}$ & $\frac{m}{\infty}$ & $\begin{array}{l}\text { 우 } \\
\text { iे } \\
\text { †े }\end{array}$ & $\begin{array}{l}\text { do } \\
\text { in } \\
\text { İ }\end{array}$ \\
\hline $\begin{array}{l}\text { N } \\
\infty \\
\infty \\
\text { + }\end{array}$ & $\frac{\stackrel{d}{~}}{\stackrel{\gamma}{*}}$ & $\begin{array}{l}\text { চे } \\
\text { ஸे }\end{array}$ & $\begin{array}{c}\dot{v} \\
\underset{m}{m} \\
\stackrel{m}{n}\end{array}$ & $\frac{d^{\circ}}{a}$ & $\begin{array}{l}\stackrel{\circ}{ } \\
\infty_{\infty}^{\circ}\end{array}$ & & $\begin{array}{l}\stackrel{0}{0} \\
\hat{n} \\
\text { ฟn }\end{array}$ & 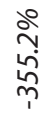 & $\frac{0}{\grave{0}}$ & 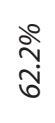 & $\begin{array}{l}\text { ఏे } \\
\text { ஸे } \\
\text { }\end{array}$ & $\frac{n}{\frac{n}{x}}$ & $\begin{array}{l}\stackrel{0}{ } \\
\text { రీ} \\
\text { ம் }\end{array}$ & $\begin{array}{l}\stackrel{2}{~} \\
\text { r̊ }\end{array}$ & 옹 & $\begin{array}{l}\text { ১े } \\
\text { ஸे }\end{array}$ & $\begin{array}{l}\text { ठे } \\
\text { هా }\end{array}$ \\
\hline 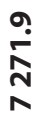 & $\begin{array}{l}\text { 우 } \\
\text { ñ } \\
\stackrel{0}{0}\end{array}$ & $\begin{array}{l}\stackrel{d}{\hat{n}} \\
\hat{n}_{1}\end{array}$ & $\begin{array}{l}\infty \\
\underset{N}{N} \\
-\end{array}$ & $\frac{d 0}{\stackrel{\infty}{\sigma}}$ & $\frac{\partial}{\text { in }}$ & $\begin{array}{l}\text { ma } \\
\stackrel{\infty}{N} \\
\end{array}$ & 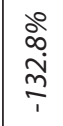 & $\begin{array}{l}\stackrel{0}{\infty} \\
\underset{\sim}{\sim} \\
\sim\end{array}$ & $\begin{array}{c}\stackrel{o}{N} \\
\text { m}\end{array}$ & $\begin{array}{l}\stackrel{0}{~} \\
\dot{m} \\
\text { r }\end{array}$ & 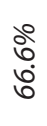 & $\begin{array}{l}0 \\
\infty \\
\infty \\
\infty\end{array}$ & $\frac{d o}{\grave{j}}$ & $\frac{d 0}{b}$ & 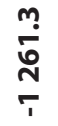 & 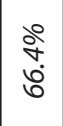 & $\begin{array}{l}\text { do } \\
\text { mे } \\
\text { m}\end{array}$ \\
\hline$\stackrel{m}{\stackrel{m}{N}}$ & 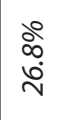 & $\begin{array}{l}\stackrel{\text { }}{~} \\
\text { ָે }\end{array}$ & $\begin{array}{l}\dot{\infty} \\
\stackrel{m}{r}\end{array}$ & $\begin{array}{l}\text { ১े } \\
\infty \\
\text { Dे } \\
\text { }\end{array}$ & \begin{tabular}{l}
$\infty^{0}$ \\
$\infty$ \\
$\infty$ \\
0 \\
\hdashline
\end{tabular} & $\begin{array}{l}\text { ஸें } \\
\text { ஸे }\end{array}$ & $\begin{array}{l}\stackrel{0}{0} \\
\stackrel{0}{0}\end{array}$ & $\begin{array}{l}\text { ळे } \\
\infty \\
\text { లై }\end{array}$ & $\begin{array}{l}0 \\
\dot{0} \\
\infty \\
0 \\
m\end{array}$ & $\begin{array}{l}\stackrel{0}{~} \\
\text { ळे }\end{array}$ & 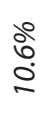 & $\begin{array}{l}\text { ọ } \\
\text { ò } \\
\text { r }\end{array}$ & $\begin{array}{l}\stackrel{0}{ } \\
\text { n̊ } \\
\text { mn }\end{array}$ & $\begin{array}{l}\text { dे } \\
\text { m. } \\
\text { in }\end{array}$ & ọ & $\begin{array}{l}\text { ১े } \\
\text { مे } \\
\text { mે }\end{array}$ & $\begin{array}{l}\text { 우 } \\
\stackrel{n}{p}\end{array}$ \\
\hline $\begin{array}{l}0 \\
\dot{m} \\
\infty \\
\infty \\
\infty\end{array}$ & $\frac{d e}{\frac{d}{a}}$ & $\begin{array}{l}\text { ठ̊ } \\
\infty\end{array}$ & $\begin{array}{l}\infty \\
0 \\
\dot{m} \\
\text { ஜூ } \\
m\end{array}$ & $\begin{array}{l}\text { oे } \\
\infty \\
\emptyset \\
0\end{array}$ & ஹั & $\begin{array}{l}\infty \\
\stackrel{\infty}{0} \\
\stackrel{\infty}{+} \\
-\end{array}$ & $\begin{array}{l}\stackrel{0}{~} \\
\infty_{\infty}\end{array}$ & 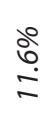 & \begin{tabular}{l} 
0े \\
$\infty$ \\
\multirow{8}{0}{} \\
0
\end{tabular} & 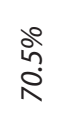 & 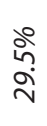 & $\begin{array}{l}\underset{+}{+} \\
\text { in } \\
\dot{v}\end{array}$ & 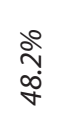 & $\begin{array}{l}\text { ô } \\
\text { in } \\
\text { in }\end{array}$ & 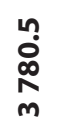 & $\frac{\text { ळे }}{\sigma}$ & $\frac{20}{\infty}$ \\
\hline$\frac{\overrightarrow{1}}{\stackrel{5}{\circ}}$ & $\ll$ & $\infty$ & $\frac{\vec{\sigma}}{\stackrel{6}{\circ}}$ & $\varangle$ & $\infty$ & $\frac{\overrightarrow{1}}{\stackrel{5}{\circ}}$ & $\ll$ & $\infty$ & $\frac{\text { 京 }}{\mathrm{O}}$ & $\ll$ & $\infty$ & 这 & $\ll$ & $\infty$ & $\frac{1}{6}$ & $\ll$ & $\infty$ \\
\hline \multicolumn{3}{|c|}{$900 z$} & \multicolumn{3}{|c|}{$\angle 00 Z$} & \multicolumn{3}{|c|}{$800 z$} & \multicolumn{3}{|c|}{6002} & \multicolumn{3}{|c|}{ OlOz } & \multicolumn{3}{|c|}{ llOZ } \\
\hline
\end{tabular}




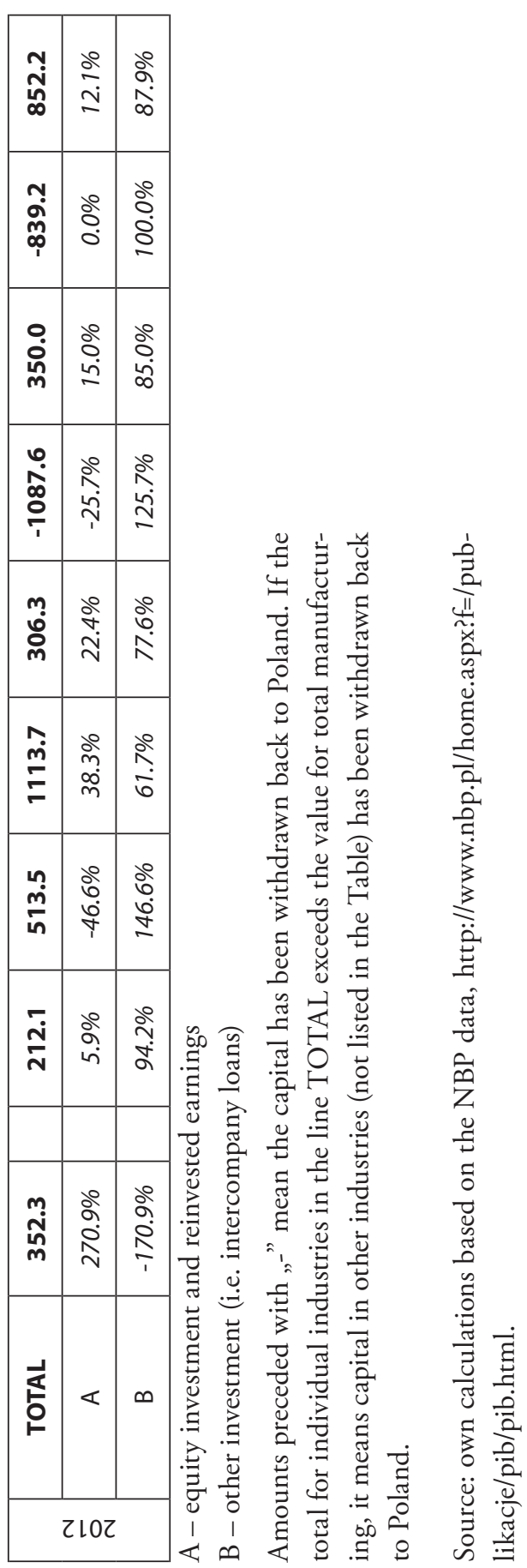


Total annual foreign direct investment of manufacturing companies ranged from less than PLN 1 bn in 2003 and 2004 to almost PLN 9 bn in 2006. Its major part was generated by food processing, refinery, chemical, metal and automotive companies as well as by the manufacturers of rubber and plastic products, machinery and equipment, and radio-TV and telecommunication equipment. At the beginning of examined period, the debt investments prevailed. It may not be surprising, as we notice that there were already strong representation of MNE's in Poland and originally owned Polish companies were not strong enough yet. After a few years of UE accession, when Polish owned companies gained more international experience, this tendency switched - majority if OFDI were primary investments. As the crisis arose, the debt component prevailed over the equity one again. This is an evidence that Polish economy remained relatively sustainable during the economic crisis and the enterprises were strong enough to support the foreign affiliates. In particular, we can observe the following cases:

- Food processing companies have intensified their expansion mainly since 2008 and invested to increase their manufacturing assets abroad. Food industry is relatively little vulnerable to economic slowdowns and the investments are predominantly horizontal ones. There exist little capital links among entities within a multinational (if so, they are related more to tax issues)

- Manufacturers of coke, refined petroleum products (which are Polish companies representing traditional branches with strong competitive advantages) were involved in relatively costly investment projects also aimed at increasing their assets. Only in 2008 capital was withdrawn to Poland in place of intense loan granting activities addressed to related companies in capital groups.

- Investment of chemical companies was diversified and it is hard to identify any single trend. It may be due to the fact, that in Poland coexist many MNE's entities together with Polish enterprises ant each of them represent different market attitude.

- Investors who manufacture rubber and plastic products were the most active especially in the last years of the studied period. For them, intense loan expansion in 2009-2010 was followed by the withdrawal of capital in 2011. It should be noticed, however, that there is strong representation of MNE's in Poland in that branch, so the debt flows may result from the need to recapitalize foreign entities suffering from crisis. 
- Manufacturers of metal and metal products got engaged mostly in increasing their manufacturing assets abroad (primary investment). The trend got reversed only in the last two years of the period;

- Manufacturers of machinery and equipment and radio, TV equipment were mainly the sources of loan capital for overseas affiliates, which can be explained by strong representation of foreign owned entities in Poland. This branch represent medium to high tech industry, so most of originally Polish companies are not strong enough, to compete successfully on international scale. That is why they do not engage in own OFDI yet.

- At the beginning, automotive companies acted as lenders, in the period 2006-2008 they made some primary investment, however, since 2009 intra-group loans dominate again. Similarly to the above mentioned medium and high tech equipment, automotive industry have a strong representation of MNE's and their FDI are dependent to the strategic decision of a parent company.

\section{Concluding remarks}

Despite a multiple theoretical and empirical literature on foreign direct investments, little attention is paid to the equity and debt breakdown of the FDI flows. While examining the scale of OFDI that distinction should be taken into account, as these two main types of flows have different sources. The first one mostly reflect the competitive advantages and strength of a company, while the latter is often a strategic decision of a parent company reflecting the flexibility of MNE's on international market or the support granted by home entities to their overseas affiliates in need. This flow, however, does not intensify international expansion understood as the increase in ownership of manufacturing assets abroad.

The investigation of Polish OFDI showed that primary investments (i.e. equity investment and reinvested earnings) account roughly for a half of the total OFDI volume. In the manufacturing sector (which represented about $35 \%$ of total OFDI) the situation was less favourable - the percentage of equity stock amounted only to about $25 \%-30 \%$ in the examined period. Moreover, equity investments originated largely from Polish-owned companies and represented so called "traditional" industries (in which Poland has comparative advantage). The latter type of investments (secondary, non-equity capital flows between related companies within capital group, mainly intercompany loans) appeared mostly in these industries, which had attracted the most IFDI stock 
to Poland (motor equipment and transportation, machinery, rubber and plastic industry), and therefore can be attributed to foreign-owned multinationals which operate in Poland. These investments resulted from relatively strong financial position of the entities located in Poland and their ability to finance related branches and subsidies of the MNE's operating in other countries.

\section{Bibliography}

Aliber R. (1970), A Theory of Foreign Direct Investment, in: Ch. Kindleberger (ed.) The international Corporation, MA: MIT Press, Cambridge.

Caves R.E. (1971), International corporations: The industrial economics of foreign investment, "Economica",vol. 38, Issue 149 (February).

Dunning J.H. (1981), Explaining the international direct investment position of countries: towards a dynamic or developmental approach, "Weltwirtschaftliches Archiv", no. 117.

Dunning J.H. (1986), The investment development cycle revisited, "Weltwirtschaftliches Archiv", no. 122.

Dunning J.H. (1988), The theory of international production, "The International Trade Journal", vol. 3.

Hartman D.G. (1984), Tax Policy and Foreign Direct Investment in the United States, "National Tax Journal", Vol. 37, No. 4 (December).

Hartman D.G. (1985), Tax Policy and Foreign Direct Investment, "Journal of Public Economics", vol. 26, issue 1 (February).

Hymer S. (1976), The International Operations of National Firms: A Study of Direct Foreign Investment, The MIT Press, Cambridge-London.

Gorynia M., Nowak J., Wolniak R. (2007), Poland and Its Investment Development Path, "Eastern European Economics", vol.45, no.2.

Gorynia M., Nowak J., Wolniak R. (2009), Poland's Investment Development Path: in search of a synthesis, "International Journal of Economic Policy in Emerging Economies", Vol. 2, no. 2.

Johanson, J., Vahlne J.E. (1977), The internationalization process of the firm A model of knowledge development and increasing market commitments, "Journal of International Business Studies", 8(1).

Karaszewski W. i in. (2012). Aktywnośc inwestycyjna polskich przedsiębiorstw za granica $w$ postaci inwestycji bezpośrednich - raport z badania, 2012 [on line] http:// www.paiz.gov.pl/wsparcie_polskich_firm, access on 28.12.2012.

Kłysik-Uryszek A. (2012), Bezpośrednie inwestycje zagraniczne przedsiębiorstw dziatających w Polsce - wstępne wyniki badań, in: U. Mrzygłód (ed) Wyzwania 
gospodarki globalnej, Prace i Materiaty Instytutu Handlu Zagranicznego, Gdańsk, no. 3.1

Kłysik-Uryszek A., Kuna-Marszałek A. (2014), Psychic and geographic distance in the process of firm internationalization. Example of companies from Poland and Lodz region, "Business and Economic Horizons", Vol. 10, issue 1.

Magee S.P. (1977), Information and the Multinational Corporation: An Appropriability Theory of Direct Foreign Investment, in: J. Bhagwati (ed), The New International Economic Order; The North-South Debate, M.I.T. Press, Cambridge,

Ozawa T. (1992), Foreign Direct Investment and Economic Development, Transnational Corporation, Feb., vol. 1, no. 1.

Rugman A.M. (1981), Inside the Multinationals - The Economics of Internal Markets, Columbia University Press New York.

Salorio E.M., Brewer T.L. (2000), Components of Foreign Direct Investment Flows: Evidence and Implications of Differences, "Latin American Business Review", Vol. 1 Issue 2

Stempkowicz W. (2007), Globalizacja gospodarki - wybrane cechy procesu, Department of Analyses and Forecasts, Ministry of Economy, Warsaw,

Umiński S. (ed.) (2009), Eksport oraz bezpośrednie inwestycje zagraniczne firm z województwa pomorskiego, PBS DGA, Wyd. UG, Gdańsk,

Wysokińska Z. (2008), Catching-Up Strategy: New Member States of the European Union in the European Internal Market for High-Tech and Environmental Products in the Context of the Renewed Lisbon Strategy, "Global Economy Journal", Vol. 8, Issue 3.

http://www.nbp.pl/home.aspx?f=/publikacje/pib/pib.html, access on 15.03.2013. 